\title{
ГИПОТИРЕОЗ И ДЕФИЦИТ ЖЕЛЕЗА В ОРГАНИЗМЕ
}

\author{
Терещенко И.В.
}

ООО «Профессорская клиника», Пермь

ЦЕЛЬ: оценить влияние сидеропении на течение гипотиреоза.

МАТЕРИАЛЫ И МЕТОДЫ: наблюдали 96 пациенток 28-63 лет с гипотиреозом. Проверяли содержание Нв и Эр. в крови, уровень ферритина, ОЖСС. Анализировали особенности течения гипотиреоза и его осложнений при сидеропении. Проводили нейропсихологическое тестирование больных. Оценивали кардиальные нарушения.

РЕЗУЛЬТАТЫ: сидеропения выявлена у 40 пациенток (1-я группа), из ниху 7 - была железодефицитная

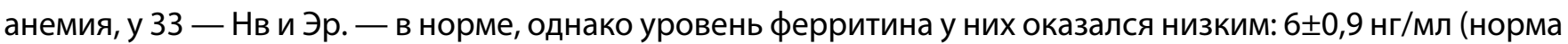
15-150 нг/мл); в среднем у больных 1-й группы уровень ферритина составил 5,1 0,7 нг/мл. У 56 больных (2-я группа) ферритин составил 79 \pm 7 нг/мл ( $<0,001)$. Гипотиреоз у всех пациенток возник в результате АИТ. Сидеропения была обусловлена не только ухудшением всасывания железа из пищи из-за гипотиреоза, но и из-за геморроидальных и/или аномальных маточных кровотечений и недостаточности железа в рационе. Сидеропения у 23 (57,5\%) пациенток обнаружена впервые, у 14 (35\%) - наблюдалась с детства, в 3 случаях проявилась в последние 3 года. Препараты железа периодически получали только 17 (42,5\%) больных. L-тироксин назначался всем больным, однако анализ медицинских документов пациенток показал наличие у них стойкого или транзиторного субклинического гипотиреоза на фоне приема L-тироксина, т.е. доза L-тироксина у них не скорректирована. Известно, и гипотиреоз, и сидеропения приводят к тканевой гипоксии; в первую очередь страдают жизненно важные органы - головной мозг и сердце. Нейропсихологическое тестирование показало у больных 1-й группы более выраженное снижение памяти, внимания, работоспособности и способности к анализу и синтезу, чем у больных 2-й группы. Тревожно-депрессивные эпизоды были у всех больных 1-й группы, во 2-й - только у 9 (16\%). Кардиальные жалобы, нарушение ритма сердца, нарушения реполяризации на ЭКГ существенно чаще наблюдались у пациенток 1-й группы. Дисфункция ЖКТ (запоры, гастрит) встретились в 100\% случаев.

ВЫВОдЫ: учитывая, что при гипотиреозе нарушается работа ЖКТ, страдает всасывание железа из пищи, нередко возникают геморроидальные и/или аномальные маточные кровопотери, должно стать правилом исключать у больных гипотиреозом сидеропению и контролировать уровень гемоглобина и ферритина в крови.

КЛЮЧЕВЫЕ СЛОВА: гипотиреоз, сидеропения, гипотиреоидная кардиомиопатия, сидеропеническая кардиомиопатия, коморбидная патология, лечение гипотиреоза. 